\title{
Ethnopedagogy And Local Genius: An Ethnographic Study
}

\author{
I Ketut Ngurah Ardiawan*1 \\ STAHN Mpu Kuturan Singaraja, Primary Teacher Education Department, 81112, Bali, Indonesia
}

\begin{abstract}
Preserving local genius is one of the ways to keep values existed in a society. In relation to that this present study aims to identify the procedures of traditional games called megoak-goakan, and reveal the ethno-pedagogy values contained within megoakgoakan. This study employs a qualitative view and utilizes ethnographic study. The setting of the study is in Buleleng regency, Bali. In order to collect the data, the researcher utilizes interview, observation sheet, and field notes. The interviewees were decided through purposive $s$ sampling. Further, there are three main components of the data analysis comprising data reduction, data modelling, and conclusion. Based on the investigation, it is revealed that the procedures of traditional game of megoak-goakan are as follows: form a group, decide the snake group and the crow groups, line up and holding each other, determine the tail of the snake, the crow starts hunting the snake tail, while the head of the snake prevents it, the crow and the snake move freely as the agreement stated, the crow shouts as it catch the tail, and winning and losing are decided by whether or not the crow is able to catch the tail. In addition, this game is also expected to bring philosophical, anthropological, sociological, and psychological values.
\end{abstract}

Keywords: Ethno-pedagogy, Local Genius, Traditional Game

\section{Introduction}

Lately, as the rapid changes in this globalization era, local genius faces great challenges to maintain itself. This is due to modern societies are interconnected globally and a culture is intervened whereby processes of globalization and identity clash each other [9, 21, 14]. In addition, [20] the exposure of globalization scrapes local culture due to an acculturation process between native culture and foreign culture. Further, [10] the effects of globalization can be destined to institutional/organisational, process, system or value driven, ideological or a combination of some of the aforementioned aspects

[14] Globalization has a direct effect to local culture. In addition, he noted that the Nigerian cultures are slowly but surely degrading. However, the effect of globalization also makes cultural identity play essential roles for the peaceful cooperation of civilization.

*stahnmpukuturansingaraja@gmail.com 
Cultural identity needs nurturing so that people in a certain society believed in where they belong and become more appreciative to their own culture while learning other cultures.[11]

In Balinese context, its multicultural tradition undergoes a number of cultural issues in its historical journey. Local Balinese ethnic who dominantly lived there has already made contact in a very long migration process with migrants ethnic, like Javanese, Buginese, Sasakese, Floresian, Timor, Minang". In reality, the current citizens have been applying educative tradition including character education. Tradition is an ancestral cultural heritage that is implemented and preserved. In this respect, one of the traditions that become focus in this study is Megoak-goakan.

A brief about megoak-goakan, it is a traditional culture and also being categorized as a local genius. This is called so due to its role to maintain moral values. Historically, this was done firstly by Panji villagers of Buleleng District, Buleleng Regency. This tradition has been played among kids and adults in Panji village. It is different from other regions; Megoak-goakan in Panji village is done in Ngembak Geni day; a series ceremonial day of Nyepi. To local villagers, Megoak-goakan is believed to have a purpose in maintaining the harmonic relationship among the people who play Megoak-goakan. However, as the time flies the implementation of this game is degrading bit by bit.

As more issues on ethnic problems are rising, ethno-pedagogy emerged as one of the approaches to deal with the aforementioned issues. In the beginning its emergence, it is considered as a branch of pedagogy. It is underpinning instructional process as nonseparated aspect with culture education $[15,8]$. Ethno pedagogy itself is defined as the model of cross cultural learning [1]. The teachers can teach by designing local culture as the media of learning that may be different from one place to another one. It is none but one way to preserve local culture in a society. Education through ethnopedagogic approach sees that indigenous knowledge as the source of innovation and expertise that can be empowered [16].

There are number of studies that supporting the use of ethnopedagogy to sustain culture by inserting it in educational process. Orshaak and Orshaak [4] focus their study on analysing Tuvanese ethnic culture in education as well as its compliance toward board knowledge. They found out that ethnopedagogy allows students to identify the degree of importance of aspects of their own culture and value orientations with the help of techniques. Focusing on Indonesian context, [1] analyse the function of Kalosara as ethnopedagogic media in nation character-building in South Sulawesi. They revealed that inserting ethnic or local culture in education let students to be more appreciative of their own culture and strengthen the relationship among people.

Similar studies are also conducted to the population in Siberian [18,19,13]. All of those experts focus on revealing the national peculiarities of physical cultures, original physical education, functions and meaning of traditional games and sports. The authors listed above express a great concern about the lack of attention to the problem of studying, preservation and implementation of traditional forms of motion activities of indigenous populations of west Siberian into education process.

As efforts should be done in preserving local genius and culture as well as how it is implemented in real situation, the researcher narrows this study to investigate the ethnopedagogical values in Megoak-goakan tradition in Buleleng regency. Likewise, the researcher focuses on two major things as follow; 1) how megoak-goakan tradition is conducted in order, and 2) what ethnopedagogical values that this tradition holds. It is expected that the result of the study will give contributions in enhancing the insight about Indonesian cultural diversity and suggestions for the government about the importance of local genius-based education. 


\section{Method}

This study employs a qualitative approach in investigating the ethnopedagogical aspects of Megoak-goakan tradition as local genius values. The study was conducted in two months starting from February to April 2017. Some stages are done covering 1) identification of problem; 2) review of data sources; 3) preparation of instrument and proposal. The second was research implementation stage, it includes: 1) data collection; 2) tabulation and data analysis; and 3) data interpretation. The third stage was construction of research report.

The subject and the scope of this study are limited to the analysis of ethnopedagogical values in Megoak-goakan tradition. The data was gathered by obtaining the information about Megoak-goakan from religious figures, society figures, and the local people that were relevant with this study. Then, the data derived from the interview was used to analyse the procedures of playing Megoak-goakan. Other than interview, this study also used observation to obtain the data. The observation method was used to see directly the procedures of playing Megoak-goakan regarding Balinese tradition ritual. This allowed the researcher to analyse the ethnopedagogical values in the procedures of playing Megoakgoakan. The researcher also documented the activities in the form of pictures. In observation process, the researchers also used field notes to record and note all of the activities during Megoak-goakan process.

Regarding the setting of the study, this study was conducted in Panji village, Sukasada district, Buleleng regency. This place was chosen because it was where Megoak-goakan historical tradition firstly occurred. Panji villagers were consistent in maintaining and preserving the local genius values in Megoak-goakan as the heritage from their ancestors. Further, the data collected then was analysed by using inductive analysis technique that as proposed by Miles and Huberman. There were four stages in the analysing process; data collection, data reduction, data presentation, and conclusion.

\section{Results and Discussion}

Based on the study that has been conducted, some result of the data will be explained as follows. Megoak-goakan was done in Ngembak Geni started from 3 p.m. until finish. The purpose of Megoak-goakan is to build good character among the society who got involve in the game. It was also an attempt to preserve the culture inherited from their ancestor.

Based on the observation and interview process, it was found that the society would firstly gather in Panji village field. After that, the people who got involve in the preparation process would drain water around the field of the game to avoid some bad injuries. There was no people who specifically organized and managed the game, therefore the teenagers would start the game by moving and running around the area of the game while inviting their friends to join them playing Megoak-goakan.

There were no specific requirements for the people who wanted to join the game. The main point was, there must be two opposite groups; one group would be seeker and another group would be the rival. There were various version of Megoak-goakan; it could be played individually or classically. When Megoakan-goakan was played individually, there would be one person acted as goak, while the opposite group made a line like a snake consisted of more than two people. On the other hand, the classical game was joined by two groups consisted of five people or more for each. The more people joined in the groups, the more fun the game would be.

This game consisted of male or female group, or it can be mixed between them as one group. There was no limitation of age; all people could join the game. Yet, it was suggested that each group should have contained of people in the same level of age and gender and 
the opposite group must have the same character with the rival group. The biggest and strongest person would stand in the frontline to lead his members. His duty was to keep his members from Goak's attack in catching the members. One person would be Goak. His duty was to catch the rival's tail as fast as he could. The time limitation was 5 minutes, if Goak could not catch the tail in 5 minutes, he would lose. Goak's rival group made a line behind the leader. They also required to hold the hip of a person who stood in front of them tightly. During the game, it was not allowed to take his friends' hip off.

There were some procedures in playing Megoak-goakan:

1) Forming a group

The group consisted of 10-20 of Panji villagers. Each group can be mixed by the gender and age.

2) Deciding the snake group and Goak group

After making two groups consist the same number of people, next step was to decide which group would be the snake and crow or Goak by using a lottery or pointed directly to the groups.

3) Making a line and holding on to each other

4) Defining the tail of the snake

5) Goak must seek and touch the tail of the snake, while the head (the leader) of the snake must block Goak's efforts.

6) Goak and snake could freely move wherever they wanted as long as it was still in the area of the game.

7) Goak players would scream goak...goak...goak....

8) The winner of the game was defined by the capability of Goak in touching or catching the person who became the tail of the snake.

After conducting the research and gathering the data systematically, it can be derived from the data analysis that Megoak-goakan tradition had ethno pedagogical values. It included philosophical value, anthological value, sociological value, and psychological value.

Megoak-goakan tradition had philosophical value for the society in Panji village in the context of their daily life. Magoak-goakan tradition was associated with Hindu philosophy that was Tri Hita Karana. Tri Hita Karana (the three causes of humans' blissfulness in life) included parahyangan, pawongan, palemahan. The philosophical values in Tri Hita Karana suggested the society to respect the whole aspect in life, it included respecting the nature, the Creator, and the humans. This also meant respecting the diversity values as one of the aspect of local genuine [3, 7].

In the implementation, Tri Hita Karana philosophy was showed by the attempts of the society to get closer with God and Goddess, and their ancestors. This was begun with the praying in Pajenengan Panji temple before playing Megoak-goakan.

In Manawa Dharmasastra III book, 76 it was stated that:

agnau prastahutih samsyag

adityam upatistate,

adityajjayate vrstir

vrsterannamtatah prajah. [5]

Translation:

The offerings put into the fire will pursue the sun, from the sun, it is followed by rain

From the rain, foods arise on which all the creatures get their life from 
It was suggested that what we got from the nature should be returned to the nature. Megoak-goakan aimed at building the stability, harmony, and conformity in ourselves. It also became the way to get closer to our Creator. Megoak-goakan as a heritage was believed having meaning to Panji society in the terms of its togetherness and harmony.

Anthropology is the study of mankind and his way of living [6]. This statement told that humans' way of life could not be separated from their basic character. Thus, anthropology is the study of various aspects of humans by learning about their various physical, society, and culture in a social-cultural interaction.

Megoak-goakan became one proof of cultural and traditional richness in Bali. Its sustainability has been maintained until now on. It did not only have a high historical value, but this tradition also provided togetherness and hardworking aspects for the players. The most recognized character in Megoak-goakan was competitiveness aspect. This allowed the society to preserve the culture and do the sport all at once. To enhance the spirit, enthusiasm, and fun atmosphere, Megoak-goakan was accompanied by bleganjur, mask usage, and traditional cloth. It implied that Megoak-goakan contained of art and cultural values in it.

The main focus of sociology study was the humans in the context of society, it included the pattern of common life or the pattern of social interaction [12]. In megoak-goakan, the players were required to work hard in attacking and defeating the rivals. This was showed by the agile movement done by the players; they ran, danced, squatted, spun, or jumped around. All of the activities that were done during the game built relationship among the players on which the local genuine values were also created. This in line with [2] who stated that sociology studies the society as a whole, it included the relationship between human and another human, human and a group, group and group, formally and materially, statically or dynamically.

Megoak-magoakan became a tool to build the sense of unity, kinship, and responsibility. These aspects were the main factors in a development and a just society on which it created a responsible sense and loyalty among the villagers. From sociological point of view, Megoak-goakan emphasizes on the socializing process. This discussion was aimed at explaining the nature of Megoak-goakan, the procedures in conducting Megoakgoakan, the values in Megoak-goakan, and the relation of the socialization process among the kids in the society

The Panji village society believed that there was a psychological kinship relationship built in Megoak-goakan. This psychological kinship relationship was built because of there was a consanguinity derived from the inhabitation and daily intercommunication. Therefore, [17] there were some grouping of psychological kinship that were made; psychological relationship based on consignation, psychological relationship based on the kinship, and psychological relationship based on the same inhabitation.

Consignation relationship meant the players or the society who got involved in this tradition were a family derived from patrilineal line of their family or they were the local people born in that village. The kinship relationship was built from the marriage between the man's family and woman's family who lived in Panji village. Psychological relationship based on the same inhabitation occurred because the people were born in Panji village.

\section{Conclusion}

Based on the result of the study, megoak-goakan traditional game has some procedures, it includes forming the groups, deciding the snake group and Goak group, making a line and holding each other, Goak must seek and touch the tail of the snake while the player who became the head of the snake must block snake's effort to catch the snake's tail, Goak 
and the snake freely moved around the area of the game, Goak players screamed 'goak' word, and the winner of the game was defined by the capability of Goak in touching or catching the person who became the tail of the snake

Megoak-goakan had local the genius-based ethnopedagogical values which covered the philosophical values, anthropological values, sociological values, and psychological value. Philosophically, Megoak-goakan tradition had philosophical value for the society in Panji village in the context of their daily life since the living society is in direct touch with Hinduism. Anthropologically, Megoak-goakan becomes one proof of cultural and traditional richness in Bali. These results become interesting to be elaborated more to give new insight in educational aspect.

The success and final outcome of this research requires a lot of guidance and assistance from many people and the researcher fortunate to have got this all along the completion of the research within the time given. I respect and thank the committees for giving the researcher to revise and complete the research based on the revision given.

\section{References}

1. A.Hafid, Amiruddin, K.Suardika,Sartono,Peribadi, Inter. Res. Jour. of Emer. Tre. in Multi. 1, 9 (2015)

2. E. Tukijan, Bahan Ajar Cetak Sosiologi Pendidikan, (Jakarta: Dirjen Dikti 2009)

3. E.E.Etta, A.E. Asira,O.O. Asukwo, Amer. Jour. of Soc. Scien. 1, 2 (2011)

4. H.D.N.Oorshak, S.Y. Oorshak, Jour. of Sib. Fed. Uni, 3, 7 (2014)

5. I.N.S. Buda, E-Journ. Fils.Pub, (2013)

6. I.W. Rasna, Jurn. Kaj. Bali, 6, 1(2016)

7. J.E. Ukpokolo,. Philosophy Interrogates Culture, (Ibadan, 2004)

8. K. Klara, O. Baktiyar, K. Sandygul, U. Saikhan, J.Gulzhiyan, Med, Jour. of Soc. Scien. 6, 1 (2015)

9. K. Otasevic, Rec. Res. in Appl. Eco. and Man. 2,1 (2011)

10. L.E.A Aimiuwu, Jour.of Nig. Inst. of Man, 39, 1 (2004)

11. M. Jones, The development of Cultural Identity in Early Childhood Settings, (De Montfort University, 2009)

12. M.C.N.R. Sri, Jurn. Kom, 7, 1 (2010)

13. N. Sinavskiy, Ethno-pedagogic of physical training of the peoples of the North (Khanty and Mansy) (Moscow, 2005)

14. O.C. Ugbam, B. Chukwu, A.Ogbo. IOSR Jour. of Buss. and Man. 16,1 (2014)

15. P. Dunbar-Hall, Act. Crit. \& Theo. for Mus. Edu. Jour. 8, 2 (2009)

16. P. Surya, Leadership of Ethnopedagogy in School (Dynamic Scientific Magazine, Yogyakarta State University, 2011)

17. S. Ndiung, S, The 1st International Conference on Language, Literature and Teaching (2017)

18. V. Krasilnikov, Folklore and national traditions in physical education of Siberian children (Chelyabinsk, Institute culture, 1998)

19. V. Krasilnikov, Games and competitions in traditional physical training of Khanti. (Yekateringurg, 2002).

20.W. I. Lasmawan, Perspektif Global dan Problematika Pendidikan Dasar. (Singaraja,Mediakom, Indonesia. 2016)

21. Y. Wang, Inter. Comm. Stu. 16, 1 (2007) 